\title{
Service Quality and Innovation in the Public Sector: A Human Values-Based Spiritual Framework
}

\author{
N. Sivakumar \\ Department of Management and Commerce, Sri Sathya Sai Institute of \\ Higher Learning, Brindavan Campus, Bangalore, Karnataka, India
}

Received December 2016; Revised May 2017; Accepted June 2017

\begin{abstract}
The public sector, being the world's largest service provider has the potential to improve the welfare of millions, if it focussed on service quality and innovation. In spite of various drivers and enablers towards better service, the public sector is seemingly tied down by several barriers. This paper studies the drivers, barriers, and enablers of the service quality and innovation of the public sector from a human values-based spiritual perspective. The paper uses the philosophy and teachings of Bhagavan Sri Sathya Sai Baba, a world spiritual leader, to understand the issues involved. The paper then develops a framework for service quality and innovation by integrating all the variables into a cohesive framework. The paper shows that the human values-based spiritual perspective can provide sustainable solutions for improving the service quality and innovation of the public sector, so that it can regain its position as a pre-eminent solutions provider.
\end{abstract}

Keywords: Public sector, spirituality, human values, service quality, innovation.

Reference to this paper should be made as follows: Sivakumar, N. (2017). Service Quality and Innovation in the Public Sector: A Human Values-Based Spiritual Framework. ICPE Public Enterprise Half-Yearly Journal, 23(1), 111-130.

\section{Introduction}

The public sector is, collectively, the world's largest service provider. Any incremental improvement in public services positively impacts millions of people (PWC, 2014). Being a large economic entity, the public sector plays an important role in the world economy. The importance of the public sector can be understood from the perspective of the objectives it is expected to achieve in a huge emerging economy, such as India, which include promoting rapid economic development through creation and expansion of infrastructure, generating financial resources for 
development, advancing redistribution of income and wealth, creating employment opportunities, promoting balanced regional growth, encouraging the development of small-scale and ancillary industries, and promoting exports on the one side and import substitution, on the other (trcollege.net, 2016).

Definitions of the public sector are varied in nature. In India, a public-sector company or undertaking refers to any corporation or company that is owned by the government (business.mapsofindia.com, 2012). However, the OECD provides a wide scope for public-sector activities by defining the public sector as the sector that includes:

All bodies, departments and establishments of government - central, state or provincial, district or county, municipal, town or village - that engage in a wide range of activities, such as: administration; defence and regulation of public order; health, education, cultural, recreational, and other social services; promotion of economic growth and welfare; and technological development. The legislature, the executive, departments, establishments and other bodies of government are also included, irrespective of their treatment in government accounts. Similarly, government-administered social security funds are also included. (OECD, 2002)

With such a wide scope, the public sector is expected to play a premier role in any economy. However, in the globally competitive open economy, the public sector has not been able to realize its true potential due to poor service quality and innovation. The 'New Public Management' (NPM) was a model introduced to reform the public sector based on sound business principles. The reforms aimed at promoting successful management techniques in old-style public bureaucracies to make them embrace a service-oriented working-style (Vigoda-Gadot et al., 2008). NPM aimed to provide a solution to the perceived lack of innovation in the public sector, caused by risk-aversion and a culture which was innovationunfriendly (Windrum, 2008).

Service quality and innovation are important issues in the public sector. In this regard, PWC (2014) commented that the reality of the public sector is that it is assessed by the efficiency of its service delivery. Improving service quality and innovation requires a change in the institutional culture of the public sector which would provide a more sustainable solution to these plaguing issues. This paper attempts to provide a long term sustainable approach towards improving service quality and innovation in the public sector from a human values-based spiritual perspective.

The spiritual viewpoint is used in this paper to create a framework for institutionalising a culture of excellence in the public sector. This attempt is emboldened by the significant evidence that the workers in the public sector were more spiritual than workers in the private sector and were more likely to 
believe in transcendence, experience interconnectedness, have higher incidences of empathy, and have a greater sense of life meaning than their private sector counterparts (Houston \& Cartwright, 2007). This approach is unique because the central premise of this paper is that a human values-based spiritual framework has the ability to provide sustainable solutions to the issues of service quality and innovation of the public sector. Eggers and Singh (2009) lamented that most often public-sector organisations do not have a lasting capacity for quality and innovation, due to quick fix methods adopted by them. Adopting a human valuesbased spiritual framework can help organisations achieve sustained excellence (AlQutop \& Harrim, 2014) by creating a larger purpose, by enabling authenticity at work, and by providing a positive feeling of vitality (Kinjerski \& Skrypnek, 2006).

This paper is organized as follows: after a review of the existing research in the area, the paper discusses the role of spirituality in the workplace. The paper then presents a human values-centred discussion of the drivers, barriers, and enablers of service quality and innovation based on the philosophy of a world spiritual leader. Finally, the paper builds a framework for service quality and innovation in the public sector from the human values-based spiritual perspective.

\section{Literature Review}

Research on service quality and innovation in the public sector has spanned several perspectives. Altshuler (1997) emphasized the need for studying the service quality public of the public sector because expectations of service quality were rising, largely because of implicit competition from the private sector. For example, when citizens visited the motor vehicle department, they expected the same kind of service they would get at McDonald's: quick, efficient, and courteous. Font (1997) suggested that public sector service quality must be evaluated from a customer perspective and it would be necessary to transfer successful experiences from the private sector to improve public services. PWC (2014) commented that changes in customer preferences and expectations were expected to be continuous for the public sector. Radical one-time changes to improve service delivery were unlikely to be a sustainable long-term solution. An institutional culture that allowed for continuous improvement was the real need of the hour. By learning from good practices across the private and public sectors and listening to its customers, the public sector would be in a position to continuously deliver on the customer promise.

Innovation in services is crucial for the sustained competitive advantage (Miller et. al, 2007). Den Hertog et. al (2010) defined service innovation as a new service experience or service solution that consisted of one or several of the following dimensions: new service concept, new customer interaction, new value system, new revenue model, new delivery system and technological expertise. Service 
innovation impacted on the customer-service provider interactions and improved the experience of finding, obtaining, installing, maintaining, upgrading and disposing of products. Service innovations delivered better self-services by eliminating waiting and allowing $24 / 7$ access via modern devices such as mobile phones, web browsers, and kiosks (IfM \& IBM, 2008).

Recent research on public sector innovation (PSI) has been attempted from various perspectives (Altschuler \& Behn 1997, Borins 1998, Albury 2005, Hartley 2005, Moore 2005). One of the research strands has been to understand the different levels of public sector innovation. Public sector innovation could occur at different levels: innovations in public administration and organization of public sector establishments, policy and regulations innovations, innovations in public campaigns and public information dissemination, innovations in revenue collection and generation, innovations in service and goods, public services or goods innovations, financial innovations, innovations in behavioural incentives provided, systemic innovations and conceptual innovations (Windrum, 2008). Based on these levels, the study suggested a taxonomy of public sector innovation comprising service innovation, service delivery innovation, administrative and organisational innovation, conceptual innovation, policy innovation, and systemic innovation.

Yet another perspective of research has been to appreciate the impact of PSI. The European Commission (2013) stated that efforts to improve innovation in the public sector were expected to have some notable public benefits such as improved productivity, efficiency of service delivery, and quality of public services. Through a metric named 'Innobarometer', the Commission explained the importance of public sector innovation. Public service innovations had a positive impact on the probability that a company would innovate. Public corporations showed improved economic and innovative performance in countries where governments managed to provide improved services for innovation and created a more businessfriendly environment. Thus, innovative and high-quality public services acted as a driver of business performance.

Research on service innovation in the public sector, too, has attracted attention. Pedersen and Nysveen, (2010) identified challenges to service innovation at three levels, namely at the policy level, at the industry level and at the firm level. In this regard, Altshuler (1997) noted that, in the public sector, innovation had never achieved significant status as a criterion of organizational excellence due to three reasons. Firstly, while government agencies faced urgent problems, passionate claimants, and muckraking journalists, they experienced little direct competition. Secondly, the political arena was characterized by high conflict; no analogue of profitability existed as a consensual criterion for appraising public sector innovations. Thirdly, people in government feared nothing more than newsworthy failure. 
Finally, there has been very little research attention on the impact of spirituality and human values in the public-sector work space. In this regard, Houston and Cartwright (2007) argued that spirituality has received attention in the literature of other disciplines, like business and social work, but not in public administration. This was quite odd given the roots of service at the core of public administration, where public service was given the status of 'a calling'. Freeman and Houston (2010) made the case that it was important to understand public administration in the context of spirituality because the effectiveness of public services may be related to the practice of religion and spirituality.

Research has shown the benefits of spirituality in the workplace. These include improved job satisfaction, better job involvement, reduced intentions to leave the workplace, increased organizational commitment, increased morality and work ethic, higher motivation, and better employee loyalty (Amirkhani \& Abadi, 2015). Moore and Casper (2006) conceived workplace spirituality as a threedimensional construct consisting of self-work immersion, interconnectedness, and self-actualisation. These dimensions were operationalised using the measures of perceived organizational support (POS), affective organizational commitment, and intrinsic job satisfaction, respectively. Using survey data, the researchers found that the operational variables were positively and significantly related to each another. Even though spiritual constructs had positive correlation with workplace relationships, the researchers cautioned that as there was no intersubjectively-certified research till date, the measures used in research were debatable. Similarly, critics of workplace spirituality have argued that secular institutions, like business firms, should restrain from imposing spiritual values on employees. However, such criticisms lost their validity when spiritual values are aimed at helping employees find meaning in their work lives and have a mission of creating a community feeling in the workplace (citeman.com, 2008).

From a service quality and innovation perspective, spirituality can play an important role. Spirituality has the ability to improve creativity and productivity, increase involvement at work, and make employees more responsible, intelligent, trustworthy, open, and confident (Miliman et al., 2003; Marques et al., 2005). These values are prime requirements for better quality and innovation.

The review of literature in this section shows that there is a need to build a framework for service quality and innovation in the public sector from a human values-based spiritual perspective.

\section{Spirituality and the Public Sector: A Human Values-Based Perspective}

There are several definitions of spirituality. Saucier and Skrzypińska (2006) defined spirituality as a subjective experience of a sacred dimension. Sheldrake (2009) 
on the other hand defined it as the deepest values and meanings by which people live. There are several ways of viewing spirituality in business, in general, and in the public sector, in particular. McLaughlin (2005) asked the question 'What is spirituality in business?' and gave a wide range of perspectives as answers:

- Treating co-workers and employees in a responsible, caring way;

- Participating in spiritual study groups or using prayer, meditation, or intuitive guidance at work;

- Making business socially responsible in the way it impacts the environment, serves the community, and helps create a better world;

- Embodying personal values of honesty, integrity, and good quality work in business.

Several researchers have emphasised the human values perspective of workplace spirituality. Lenka et al. (2010) stated that workplace spirituality is a framework of organizational values. Fawcett et al. (2008) considered that a spirituality-based organisation and a values-based organisation were one and the same. Further, at the root of the discussion of spirituality in the workplace was the notion of core values, which fostered a sense of connectedness and wholeness within the organization that facilitated individual and organizational growth. At a deeper level, McLaughlin (2005) stressed that the spirit in the business movement was a practical demonstration of the spiritual laws and principles, which were guiding the next step in human evolution. The spiritual approach worked towards honouring the essential divinity in each person.

There are several advantages of using a human values-based spiritual framework to address the issues of service quality and innovation. Firstly, as discussed earlier, a spiritual approach can provide a strong foundation for sustainable business excellence. Secondly the spiritual approach aims at individual transformation leading to organisation wide transformation. In this regard, Teeroovengadum and Teeroovengadum (2012) have pointed out that by putting people first, the human values-based spiritual approach committed individuals towards quality and innovation. Thirdly, the spiritual approach inspires the leaders of organisations to be role models in the quest of quality and innovation. Fry et al. (2017) have analysed the winners of the Malcolm Baldrige award and found that spiritual leadership had an important role in achieving quality and excellence. Finally, in an era of ecological challenges, it is necessary to ensure that improvements in quality and innovation also take into account their impact on the environment. The human values-base spiritual framework keeps this as an important part of excellence, working towards a triple bottom line.

Regarding assessment of workplace spirituality, Giacalone and Jurkiewicz (2003) identified ten value measures of spirituality at work: benevolence, generativity, integrity, humanism, justice, mutuality, receptivity, respect, responsibility, and 
trust. Further measures and assessments have been developed by Shankar (2009), Steingard and Dufresne (2013), and Soder (2016), among others. This paper uses the human values perspective of spirituality to discuss the issue of public sector service quality and innovation.

\section{Human Values-Based Spirituality: The Philosophy of Bhagavan Sri Sathya Sai Baba}

Bhagavan Sri Sathya Sai Baba (referred to as Baba henceforth), who is venerated by millions as a foremost spiritual leader, has expounded the concept of spirituality from a human values perspective (for more information about Baba, the interested reader is referred to www.srisathyasai.org.in). Baba defines spirituality as the process of eliminating the baser values in each individual, cultivating higher human values and finally manifesting sublime values (Baba, 1999-2010, vol. 25).

Baba further elucidates that spirituality calls for the recognition of the manifold capacities manifesting in each person as emanating from the Spirit. It calls for developing the faith that all strength come from the Divine. Spirituality is thus the expression of the promptings of the 'Inner Spirit'. Spirituality should be an integral part of daily life. According to Baba, it is totally wrong to think that daily concerns have no relation to spirituality. Spirituality is the realisation of the role of the spirit in daily life. It is a way of life. Ultimately, spirituality seeks to unfold the divinity in each individual. Baba emphasises that true spirituality calls for the recognition of the oneness of all creation and the demonstration of the spiritual truth underlying this divine unity (Baba, 1999-2010, vol. 25).

The major human values manifested through spirituality include truth, right action, peace, love and non-violence (Baba, 1999-2010, vol. 19). The various facets of spirituality as outlined above show that Baba's philosophy is quintessentially 'Sanathana Dharma' (eternal human values). Such a human values-based spiritual philosophy is universal and not culturally dependent. Mitroff (2003) and Jacobs (2011) asserted that spiritual values are universal and timeless. Using intercultural theory, Reave (2005) showed that spiritual values like respect, compassion, and appreciation go beyond the limitations of culture.

The philosophy propounded by Baba has found its applications in several projects and institutions which promote social welfare. These projects encompass a wide variety of areas like medical care, education, and social care. The uniqueness of these projects is that the benefits of all these projects are offered to all beneficiaries without any discrimination and free of cost. This has resulted in the creation of a values-based institute of higher learning (Sri Sathya Sai Institute of Higher Learning), a super specialty hospital and a water 
supply project, which helps a population of more than a million (Chaden, 2004). The institute of higher learning has the vision of imparting values-based education creating citizens who have zeal to promote social welfare (Arweck \& Nesbitt, 2007). It is interesting to note that alumni of Sri Sathya Sai Institute of Higher Learning have joined several public-sector institutions and they actively follow Baba's teachings in their workplace (Aitken, 2004).

The current paper is therefore an endeavour in applying Baba's philosophy in understanding complex global issues, such as the public-sector services. The focal thrust of the paper is to emphasize that a human values-based spiritual approach can lead to sustainable public-sector service quality and innovation that can ultimately promote social welfare. In the following section, the issues related to public sector service quality and innovation have been discussed in relation to the human values-based spiritual philosophy of Baba.

\section{Public Sector Service Quality and Innovation: A Spiritual Perspective of Drivers, Enablers and Barriers}

Service quality can be defined as a form of attitude of customers that results from a comparison of expectations with perceptions of service performance (Parasuraman et al., 1988). Gronroos (1984) classified service quality as technical quality and functional quality. Good service quality was the consistency of customer quality experience with expected quality experience.

Service innovations are generally about offering new or adapted solutions to the customer's needs in ways that enhances the perceived value of the offering (Jairam, 2013). Service innovation is defined as a combination of technology innovation, business model innovation, social organisational innovation, and demand innovation with the objective to improve existing service systems (incremental innovation), create new value propositions (offerings) or create new service systems (radical innovation) (IfM and IBM, 2008).

The public sector has several drivers, enablers, and barriers to service quality and innovation which have been discussed from a human values-based spiritual perspective.

\section{Drivers}

A combination of internal or external pressures is driving the public sector towards better service quality and innovation. With regard to service quality, customer expectations are the prime driver. In this regard, Nor et al. (2010) observed that public-sector organizations agree that customer service is one of the most important 
vital factors that contribute to the establishment of reputation and credibility among the public. Complaints of long queues, poor service deliver, and insufficient physical facilities may affect the image and level of service quality in the public sector. Increased customer expectations are therefore driving the public sector to improve their service quality. On the other hand, according to Borins (1998), internal issues within an agency or department are the most frequent drivers for innovation. Human resources themselves are internal drivers. The middle management and front-line levels contain many younger, often recent university graduates who are close to day-to-day operations as well as close to cutting-edge thinking they encountered recently at universities. The new thinking of younger executives makes them to design innovative ways of providing public services.

It is useful to note that both the internal and external drivers mentioned above lead to reactive approaches towards service quality and innovation. To be true, the public sector has been reacting because its customers or new age employees have been forcing it to do so. Reactionary approaches to service quality are perilous. Thompson (2016) stated that the weakness of reactionary strategies is that they lead to customer or employee dissatisfaction. Even without an indication, dissatisfied customers may simply go elsewhere for service the next time and advise others to do the same. Schulze (2014) stated that reactionary approaches ultimately lead to fire-fighting and finger-pointing. Similarly, Eggers and Singh, (2009) pointed out that typically innovation in government happened in one of two ways. Either innovation intrudes itself on a public-sector organisation in response to a crisis, or some individual (or small group of individuals) champions a specific innovation. In either instance, the benefits of the innovation are limited. Once the crisis has passed or certain individuals responsible for the innovation have moved on, the organisation is left with no lasting capacity for innovation.

The spiritual perspective, on the other hand, gives prominence to proactive behaviour. Spirituality emphasises that love is the prime undercurrent for all human values (Baba, 1999-2010, vol.18). Love creates proactive behaviour. In this regard, Baba stresses that 'Love without duty is Divine. Duty implies force or compulsion, while love is spontaneous and expresses itself without external promptings' (Baba, 1999-2010, vol.14). Baba further explains that a proactive approach to service leads to the practice of the sublime value of sacrifice, while a reactive approach is inclined more towards the baser instincts of gaining publicity (Baba, 1999-2010, vol.11). Baba urges that professionals in the areas of education, health care, legal services, and business must reach out to the needy to render services proactively (Baba, 1999-2010, vol.21).

Scholars have emphasised the benefits of proactive approaches towards service quality and innovation. Proactive approaches attempt to utilise the embedded value of firms effectively to retain customers. In a proactive mode, service quality and innovation gets enhanced due to collaboration among service 
providers and sharing of best practices (Schulze, 2014). In this regard, it is useful to note that recently Public Power Solutions, a UK based public service unit, was declared as the most proactive public sector body in the UK. The company has built UK's first Solid Recovered Fuel (SRF) Plant in Swindon, bringing together the best of the public and commercial sectors to deliver an innovative waste solution that benefits the Swindon Borough Council and local communities. The SRF plant has helped in diverting $97 \%$ of Swindon's municipal waste from landfill, has saved the council over $£ 1.6 \mathrm{~m}$ in landfill tax, and has facilitated in producing a valuable energy generating resource which has been replacing fossil fuels (www. publicpowersolutions.co.uk, 2016).

\section{Barriers}

Research has identified several barriers to service quality and innovation in the public sector (Commonwealth of Australia, 2010; European Commission, 2013). These typically include lack of human or financial resources, strict regulatory requirements, lack of management or political support, inadequate time availability, risk-aversion, external opposition, lack of discussion on failed innovations, innovation not being a strategic priority, public sector operating in silos, influence of political factors, lack of competition and profit motive, want of rewards for risk-taking or successes, excessive bureaucracy, and low pay scales.

A review of these barriers quickly points out to an important tendency in the public sector, which is shifting the blame for the lack of service quality and innovation to conditions which seemingly cannot be easily changed. This helps the organisation to justify its existing position and maintain its status quo. In this regard, the United Nations (2005) stated that "an organizational culture dominated by rigid adherence to rules and regulations very seldom encourages staff to ask challenging questions and to alter the status quo. In many public services, in fact, the practice of questioning the status quo is not in accord with conventions, and in some instances, the practice is even actively discouraged". With regard to service innovation in public services, it has been shown that while re-imagined public services in a digital age can create huge opportunities for smarter, more efficient, citizencentric public services, these can also be seen a threat to the status quo and a challenge to long established procedures and values (nesta.org.uk, 2016).

Therefore, the challenge for many reform-minded governments is often to radically change the mindsets of both leaders and public servants in order to allow for new forms of communication, initiative-taking and learning to improve public service and innovation (United Nations, 2005). However, these reforms face tremendous resistance to change (Madinda, 2014).

King (2010) suggested that successful change efforts in the public sector have 
to start with a vision of radically improved performance and the relentless organization-wide pursuit of that vision. It has to be an introspective and inclusive process by which an organization formulates its values and revisits its mission that allows organizations to serve their customers and communities, to be viable and relevant in an uncertain future. A spiritual perspective can effectively ease this process by enabling appropriate values of selfless service and compassion.

In this regard, Baba (1999-2010, vol. 11) gives the following guidelines for true service:

- Rendering service selflessly with a compassionate heart alone is true service.

- One should be looking at all times, even beyond the horizon of one's allotted tasks for any extra opportunity to serve.

- Every act done with sympathy and skill to anyone in distress is true service.

- Compassion must express itself in action to relieve the suffering. True compassion should emanate from the heart.

Baba (1999-2010, vol. 23) states that a transformation towards compassionate service must begin with the individual. Individual change has the potential to trigger a global change. Thus, spirituality emphasises that organisation wide transformation has to first start with individual transformation.

When values of selfless service and compassion are inculcated in the culture of public sector organisations, it will reduce any resistance to change to improve service quality. Cultivating compassion in the workplace is essential to improve quality. In this regard, McLaughlin (2005) described the instance of managers and union workers of Southern California Con Edison attending sessions called "The Heart Shop" to cultivate compassion for each other, creativity, and a new intelligence of the heart. Similarly, King (2010) recorded the instances of profound transitions that have happened in the public sector in the recent times. Several major transformation efforts can be observed across the U.S. federal government, in agencies as diverse as the Department of Defence, United States Postal Service, Internal Revenue Service, Centre for Disease Control, and the Government Accountability Office.

\section{Enablers}

Several establishments, such as the European Union, Australian Government, and PWC have attempted to measure service quality and innovation in the public sector (Commonwealth of Australia, 2010; European Commission, 2013; PWC, 2014). One of the important criteria used for measurement are the enablers of quality and innovation, which include the share of employees in public administration with 
a university degree pursuing 'creative occupations', government effectiveness, and regulatory quality through the use of ICT, and online availability of public services measured using the e-government development index (EGDI).

A cursory look at these enablers shows the emphasis on the usage of technology to innovate and effectively deliver public services. PWC (2014) stated that, bearing in mind the relentless pressure they are under to meet customer expectations, public sector organisations should focus first on improving front-end service delivery capabilities, before tackling back-end processes. This is where technology can play the role of an enabler, by 'allowing things to happen', facilitating connected government through improved data sharing and collaboration in service delivery. Similarly, the Commonwealth of Australia (2010) observed that technology is re-shaping public interactions with business and government and increasing public expectations of engagement and service delivery. To realise these expectations and to capture the value of engagement, agencies should be timely and smart adopters of Web 2.0 tools and approaches. Technology in public services, whether it is banking or tax services, is being used as a tool to reduce human interface (NACEN, n.d).

There is no doubt that technology has played the role of the prime enabler to improve public sector services. However, Commonwealth of Australia (2010) thoughtfully observed that, "while technology should be used primarily as an enabler of transformation, we see an increasing number of public sector leaders trusting in it as a universal panacea for aligning public sector service delivery with customer needs'. The overemphasis on technology has led to two important consequences: indiscriminate use of technology and technology without a human face. Digital Green (2013) argued that the indiscriminate use of technology had actually precipitated an agrarian crisis across the world. Further, the indiscriminate use of technology had led to unsustainable use of resources impacting the future generations adversely. Overemphasis on technology usage leads to technology without the human face. Gandhi and Joseph (2005) pointed out that technology without a human face cannot lead to social transformation. Science and technology without the human element can be used for purposes that are dangerous and antiecological.

Overemphasis on technology undermines human values and spirituality. Baba (1993) exhorts thus:

the whirlwind of the rapidly progressing science and technology, coupled with its commercialisation, is bringing about undesirable changes in our society by way of uprooting the moral or ethical values so essential for human well-being. Science and technology have, no doubt, contributed substantially to material progress; but they have altogether undermined spiritual values such as 
selflessness, divinity, and dignity inherent in man. In a way, they have devalued humanity itself so much so that the present generation of young men and women are unable to recognise their divine nature. They are considering self-centredness as the goal of life. Evil qualities like ostentation, egoism, and excessive and empty talk are playing their devil dance in society.

What is therefore required for service quality and innovation in the public sector is technology blended with human values. Baba (1999-2010, vol. 12) gives the solution: as science develops and technology advances, humility and love should also develop to the same extent. Pizzati (2012) termed institutions and people who integrate technology and spirituality as 'Technoshamans' and emphasised that technology imbued with spirituality and human values was the true need of the hour.

Public sector institutions do need to use technology with caution. As the Commonwealth of Australia (2010) urges, 'in the world of technology-enabled service, there is still no substitute for 'old fashioned qualities', such as courtesy, friendliness and caring. An important aspect from the perspective of the citizen is the relevance and engagement with which services are delivered. This is particularly true for social services where personal contact is essential'. It is also important to recognise that 'eGovernment is not about technology, but, it is about people; it is about putting the citizen in the centre.'

As discussed in this section, when the drivers, barriers and enablers of public sector service quality and innovation are understood from a spiritual human values-based perspective, they get added meaning and significance.

\section{Public Sector Service as a 'Calling': The Human Values-Based Spiritual Framework}

The previous section studied the major drivers, barriers, and enablers of public sector service quality from a spiritual perspective. This section combines the major understandings of these discussions into an integrated framework. This is presented in Table 1. 
Table 1

Human Values-Based Spiritual Framework of Public Sector Service Quality and Innovation

\begin{tabular}{|c|c|c|c|c|}
\hline \multirow{2}{*}{ Issue } & \multicolumn{2}{|c|}{ Existing perspective } & \multicolumn{2}{|c|}{ Human values-based spiritual perspective } \\
\hline & Emphasis & Implication & Emphasis & Implication \\
\hline Drivers & $\begin{array}{r}\text { Customer } \\
\text { expectation and } \\
\text { innovation } \\
\text { champion driven. }\end{array}$ & $\begin{array}{r}\text { Reactionary in } \\
\text { nature. Always on } \\
\text { fire-fighting mode. } \\
\text { Non-sustainable. }\end{array}$ & $\begin{array}{r}\text { Love, service, and } \\
\text { sacrifice. }\end{array}$ & $\begin{array}{r}\text { Proactive in nature - } \\
\text { reaching out to serve. } \\
\text { Sustainable service and } \\
\text { innovation. }\end{array}$ \\
\hline Barriers & $\begin{array}{r}\text { Existing conditions } \\
\text { are deep seated and } \\
\text { difficult to change. }\end{array}$ & $\begin{array}{r}\text { Encourages status } \\
\text { quo in behaviour. } \\
\text { Discourages } \\
\text { challenging the } \\
\text { current situation. }\end{array}$ & $\begin{array}{r}\text { Individual } \\
\text { transformation-based } \\
\text { organisation change. } \\
\text { Transformation based } \\
\text { on creativity and } \\
\text { service. }\end{array}$ & $\begin{array}{r}\text { Creates an organisation } \\
\text { culture of profound } \\
\text { transformation and } \\
\text { relentless pursuit of } \\
\text { perfection. }\end{array}$ \\
\hline Enablers & $\begin{array}{r}\text { Overemphasis on } \\
\text { technology. } \\
\text { Technology viewed } \\
\text { as a panacea. }\end{array}$ & $\begin{array}{r}\text { Indiscriminate use } \\
\text { of technology. } \\
\text { Technology without } \\
\text { a human face and } \\
\text { aiming to reduce } \\
\text { human interface. }\end{array}$ & $\begin{array}{r}\text { Technology } \\
\text { integrated with } \\
\text { spirituality. }\end{array}$ & $\begin{array}{r}\text { Appropriate use of } \\
\text { technology. Importance } \\
\text { of human values of } \\
\text { courtesy, friendliness, } \\
\text { dignity, and caring in } \\
\text { service and innovation. }\end{array}$ \\
\hline
\end{tabular}

The above table shows how the drivers, barriers, and enablers of public sector service quality and innovation can be viewed from a different perspective using the lens of human values and spirituality.

The managerial implications of this perspective are profound. Firstly, public sector institutions must work towards creating corporate cultures that emphasise performance excellence based on a higher mission of social welfare. With such a distinctive culture, they are more likely to attract a wider pool of candidates who are genuinely inspired by the organisation's service ideals. Their level of commitment to the organisation's objectives, combined with technology, would help to ensure the delivery of improved customer services (PWC, 2014). Secondly, the spiritual framework emphasises excellence based on individual transformation. This puts the onus on the leaders of public sector to act as role models of service quality and innovation to inspire others in their organisations. Thirdly, it is important to note that the framework discourages indiscriminate use of technology. Technology needs to be wedded with spiritual values so that it can have a lasting impact. Finally, it is essential to realise that public-sector service is a calling. This understanding would ensure that policies created would maximise the value of all stakeholders concerned rather than just financial stakeholders.

While the framework mentioned in this section can provide sustainable improvements to public sector service quality and innovation, certain precautions need to be taken in its understanding and implementation. Spiritual values are 
based on inner individual transformation. In this regard, Baba (1999-2010, vol. 26 points out that spiritual values must be cultivated from the inner 'source' rather than through external 'force'. This implies that in the enthusiasm to create a culture of sustained excellence, spiritual values should not be imposed on people. Instead a conducive environment which inspires the practice of these values must be created. Further, in this context, it should be understood that such an environment cannot be created without the leadership of the organisations espousing these values. It is would be meaningless if leadership actions show disregard to the practice of these values. Creating a culture of sustained excellence based on spiritual values should be seen as a long-term endeavour and not as a quick fix solution.

\section{Directions for Future Research and Conclusion}

Further research is possible in this direction. It is possible to study the cases of public sector service excellence and understand whether a human values-based spiritual framework has been the undercurrent inspiring force. Employees of public sector institutions can be studied to understand the intricacies involved in institutionalising a culture based on spiritual values. It would be useful to develop standardised metrics and assessments to study drivers, enablers, and blocks to service quality and innovation from a spiritual values perspective. Initiation of research in these areas would go a long way in providing sustainable solutions to the public sector.

Houston and Cartwright (2007) lamented that 'the common pronouncement of a career in public service as a "calling" echoes with a decidedly spiritual chord. However, the spiritual roots of public service have been ignored in much of the public administration scholarship'. This paper attempted to show that developing a perspective of spirituality based on human values can provide a long-lasting solution to this perplexing issue. When firms sincerely adopt this perspective, they can realise their true potential of working towards a better and more welfare oriented society.

\section{References}

Aitken, B. (2004). Sri Sathya Sai Baba: A Life. Penguin Books India, New Delhi. Albury, D. (2005). Fostering innovation in public services, Public Money and Management, 51-56.

Al-Qutop, M. A. Y., \& Harrim, H. (2014). Spiritual organization: A path to organizational sustainable excellence. International Business Research, 7(8), 168178.

Altschuler, A., \& Behn, R. (1997). Innovations in American Government. Washington: Brookings Institution. Altshuler, A. (1997). Bureaucratic innovation, 
democratic accountability, and political incentives. In A.

Altshuler and R. D. Behn (Eds.), Innovation in American government: Challenges, opportunities, and dilemmas (pp. 38-67). Washington, DC: Brookings Institution Press.

Amirkhani, A. H., \& Abadi, Z. F. S. (2015). Studying the effect of spirituality on the quality of the working environment and organizational commitment. International Research Journal of Management Sciences, 3(10), 482-495.

Arweck, E., \& Nesbitt, E. (2007). Spirituality in education: Promoting children's spiritual development through values. Journal of Contemporary Religion, 22(3), 311-326.

Baba, B. S. S. S. (1999-2010). Sri Sathya Sai Speaks (Vol. 1-42). Puttaparthi, India: Sri Sathya Sai Sadhana Trust, Publications Division.

Baba, B. S. S. S. (1993). Summer Showers 1990. Puttaparthi, India: Sri Sathya Sai Sadhana Trust, Publications Division.

Borins, S. (1998). Innovating with Integrity. Washington, DC: Georgetown University Press. business.mapsofindia.com. (2012). Public Sector Undertaking. Retrieved from

http://business.mapsofindia.com/sectors/public/

Chaden, C. L. (2004). A Compendium of the Teachings of Sri Sathya Sai Baba. Bangalore, India: Sai Towers Publishing.

citeman.com. (2008). Criticisms of spirituality. Retrieved from http://www.citeman. com/3115-criticisms-of-spirituality.html

Commonwealth of Australia. (2010). Empowering Change: Fostering innovation in the Australian public sector. Retrieved from http://www.apsc.gov.au/ publications-and-media/archive/publications-archive/empowering-change.

Den Hertog, P., van der Aa, W., \& de Jong, M. (2010). Capabilities for managing service innovation: towards a conceptual framework. Journal of Service Management, 21(4), 490-514.

Digital Green. (2013). Feed the future. Retrieved from https://www.spring-nutrition. org/sites/default/files/2.6d-lakshmi.iyer_-_small.pdf.

Eggers, W. D., \& Singh, S. K. (2009). The public innovator's playbook: nurturing bold ideas in government, Deloitte Research. Retrieved from http://www.deloitte. com/dtt/cda/doc/content/dtt_ps_innovatorsplaybook_100409.pdf.

European Commission. (2013). European Public-Sector Innovation Scoreboard 2013. A pilot exercise. Technical Report. Belgium: European Union.

Fawcett, S. E., Brau, J. C., Rhoads, G. K., Whitlark, D., \& Fawcett, A. M. (2008). Spirituality and organizational culture: Cultivating the ABCs of an inspiring workplace. Intl Journal of Public Administration, 31(4), 420-438.

Font, J. (1997). Quality measurement in Spanish municipalities: transferring private sector experiences. Public productivity \& management review, 44-55.

Freeman, P. K., \& Houston, D. J. (2010). Belonging, believing, behaving: The religious character of public servants. Administration \& Society, 42(6), 694-719.

Fry, L. W., Latham, J. R., Clinebell, S. K., \& Krahnke, K. (2017). Spiritual leadership as a model for performance excellence: a study of Baldrige award recipients. Journal 
of Management, Spirituality \& Religion, 14(1), 22-47.

Gandhi, P. J., \& Joseph, M. J. (2005). Public-Private Partnership in Nation Building. India: Deep and Deep Publications.

Giacalone, R. A., \& Jurkiewicz, C. L. (2003). Right from wrong: The influence of spirituality on perceptions of unethical business activities. Journal of Business Ethics, 46(1), 85-97.

Gronroos, C. (1984). A service quality model and its marketing implication. European Journal of Marketing, 18(4), 36-44.

Hartley, J. (2005). Innovation in governance and public services: past and present. Public Money and Management, 25, 27-34.

Houston, D. J., \& Cartwright, K. E. (2007). Spirituality and public service. Public Administration Review, 67(1), 88-102.

Houston, D. J., \& Cartwright, K. E. (2007). Spirituality and public service. Public Administration Review, 67(1), 88-102.

IfM \& IBM. (2008). Succeeding through service innovation: A service perspective for education, research, business and government. Cambridge, United Kingdom: University of Cambridge Institute for Manufacturing.

Jacobs, G. (2011). The Turn Towards Unity: Converting Crises into Opportunities. Cadum, 1(3), 106.

Jairam, V. A. (2013). Adding service innovation to the value equation. Master's thesis of Maastricht School of Managment, Retrieved from http://www.fhrinstitute. org.

King, J. (2010). Leading Change in the Public Sector. Virginia: Walnut Ridge Consulting.

Kinjerski, V., \& Skrypnek, B. J. (2006). Measuring the intangible: Development of the spirit at work scale. In Academy of Management Proceedings (pp. A1-A6). Academy of Management.

Lenka, U., Suar, D., \& Mohapatra, P. K. (2010). Soft and hard aspects of quality management practices influencing service quality and customer satisfaction in manufacturing-oriented services. Global Business Review, 11(1), 79-101.

Madinda, A. S. C. (2014). Challenges facing management of change in public sector: The Case of Tanzania. International Journal of Education and Research, 2(7), 161176.

Marques, J., Dhiman, S., \& King, R. (2005). Spirituality in the workplace: developing an integral model and a comprehensive definition. The Journal of American Academy of Business, 7(1), 81-91.

McLaughlin, C. (2005). Spirituality and ethics in business. European Business Review, 17(1), 94-101.

Miller, D., Fern, M., \& Cardinal, L. (2007). The use of knowledge for technological innovation within diversified firms. Academy of Management Journal, 50(2), 307325.

Milliman, J., Czaplewski, A. J., \& Ferguson, J. (2003). Workplace spirituality and employee work attitudes. An exploratory empirical assessment. Journal of Organizational Change Management, 16(4), 426-447. 
Mitroff, I. I. (2003). Do not promote religion under the guise of spirituality. Organization, 10(2), 375-382. Moore T. M., \& Casper, W. J. (2006). An examination of proxy measures of workplace spirituality: a profile

model of multidimensional constructs. Journal of leadership and organizational studies, 12(4), 109-118.

Moore, M. H. (2005). Break-through innovations and continuous improvement: two different models of innovative processes in the public sector. Public Money and Management, 25, 43-50.

NACEN. (n.d). Change management for implementation of simplified tax regime. Retrieved from http://nacen.gov.in/inspire/uploads/downloads/569c931d87e85.pdf. nesta.org.uk. (2016). Innovation in the public sector: Is risk aversion a cause or a symptom? Retrieved from http://www.nesta.org.uk/blog/innovation-public-sectorrisk-aversion-cause-or-symptom.

Nor, M. N., Khalid, S. A., Razali, M. F. M., \& Ramli, N. A. (2010). Service quality and customer satisfaction: The public-sector perspective. Faculty of Business and Management, Universiti Teknologi MARA, Perlis.

OECD. (2002). The Frascati Manual:

Institutional Classification. Retrieved from http:/www.studfiles.ru/preview/1840522/page:8/

Parasuraman, A., Zeithaml, V. A., \& Berry, L. L. (1988). SERVQUAL: A multiple item scale for measuring customer perceptions of service quality. Journal of Retailing, 64, 12-40.

Pedersen, P. E., \& Nysveen, H. (2010). Service innovation challenges at the policy, industry, and firm level: A qualitative enquiry into the service innovation system (Working Paper No. 10/10). Institute for Research in Economics and Business Administration, Bergen. Retrieved from

http://www.snf.no/Files/Filer/Publications/A10_10.pdf

Pizzati, C. (2012). Technoshamans: Between Spirituality and Technology - a Journey to the End of the World to Cure a Chronic Backache. Bloomington: AuthorHouse.

Powersolitions.uk. (2016). Public Power Solutions named Most Proactive PublicSector Body. Retrieved from https:/www.publicpowersolutions.co.uk/

PWC. (2014). The road ahead for public service delivery: Delivering on the customer promise. Public Sector Research Centre. Retrieved from

https://www.pwc.com/gx/en/psrc/pdf/the_road_ahead_for_public_service_delivery. pdf

Reave, L. (2005). Spiritual values and practices related to leadership effectiveness. The Leadership Quarterly, 16(5), 655-687.

Saucier, G., \& Skrzypińska, K. (2006). Spiritual but not religious? Evidence for two independent dispositions. Journal of Personality, 74(5), 1257-1292.

Schulze, M. (2014). Operational Performance Management in CEP. Retrieved from https://www.business-code.de/wp-content/themes/bcdtheme/ download/2014-05-17\%20BusinessCode\%20Operational\%20Performance $\% 20$ in\%20CEP.pdf.

Shankar, P. B. (2009). Individual spirituality, workplace spirituality and work 
attitudes: An empirical test of direct and interaction effects. Leadership \& Organization Development Journal, 30(8), 759-777.

Sheldrake, P. (2009). A brief history of spirituality. Wiley-Blackwell.

Soder, P. F. (2016). Workplace spirituality and employee work intentions: examining the relationship and the mediating role of ethical leadership. Electronic Theses and Dissertations. Paper 2569. Retrieved from http://ir.library.louisville.edu/cgi/ viewcontent.cgi? article $=3694 \&$ context $=$ etd

Steingard, D. S., \& Dufresne, R. L. (2013). The evaluative framework for workplace spirituality assessments: working our strengths and strengthening our work. In J. Neal (Ed.), Handbook of Faith and Spirituality in the Workplace (pp. 455-487). New York, NY: Springer.

Teeroovengadum, V., \& Teeroovengadum, V. (2012). The Need for Individual Transformation in Building a Learning Organisation in the 21st Century. International Journal of Learning, 18(12), 1-14.

Thompson, S. (2016). Difference Between a Proactive \& a Reactive Business Strategy. Retrieved from http://smallbusiness.chron.com/difference-betweenproactive-reactive-business-strategy-62157.html.

trcollege.net. (2016). Public sector in India. Retrieved from http://www.trcollege. net/study-material/24-economics/44-public-sector-in-india.

United Nations. (2005). Unlocking the Human Potential for Public Sector Performance: World Public Sector Report 2005. New York.

Vigoda $\square$ Gadot, E. R. A. N., Shoham, A., Schwabsky, N., \& Ruvio, A. (2008). Public Sector Innovation for Europe: A Multinational Eight $\square$ Country Exploration of Citizens' perspectives. Public Administration, 86(2), 307-329.

Windrum, P. (2008). Innovation and entrepreneurship in public services. In P. Windrum and P. Koch (Eds.), Innovation in Public Sector Services, Edward Elgar, Cheltenham.

\section{Author Note}

The author is thankful for the useful comments received from two anonymous reviewers, which helped to improve the quality and presentation of the present manuscript. The author humbly dedicates this paper to Bhagavan Sri Sathya Sai Baba, The Revered Founder Chancellor of Sri Sathya Sai Institute of Higher Learning, Prasanthinilayam, India.

Correspondence concerning this article should be addressed to N. Sivakumar, Department of Management and Commerce, Sri Sathya Sai Institute of Higher Learning, Brindavan Campus, Bangalore 560067, Karnataka, India. Email: nsivakumar@sssihl.edu.in 


\section{Biographical Note}

N. Sivakumar is an Associate Professor in the Department of Management and Commerce, Sri Sathya Sai Institute of Higher Learning, Brindavan Campus, Bangalore, India. He has almost 30 years of teaching and research experience. His area of research is Values-Based Management. He has published over 100 research papers in journals and presented his research at numerous conferences. 